\title{
Law and politics in international relations; reflections of a politics-oriented reader on a law-oriented book: a review
}

\author{
Wallace McClure, $W$ orld legal order
}

INIS L. CLAUDE, JR.

\section{University of Michigan}

This is in many ways a rather trying book. The author exhibits a passion for lengthy narration and quotation which transforms virtually every citation of a legal case or mention of an incident into a long-winded anecdote, replete with factual detail and padded with the texts of judicial opinions, United Nations resolutions, and the like. The lawyer's love of the professional jargon, which specializes in Latin tags, prevails even to the point of reference to "a domus divided against itself" (p. 101); the author's infatuation with a particular prefix leads him to coin such a monstrosity as "the suprasupreme Constitution" (p. 43). Beyond this, there is an undisciplined quality about the book which is reflected in the fact that France's reservation concerning the acceptance of the compulsory jurisdiction of the World Court is treated in chapter ix, while discussion of the same topic in relation to the United States is held back for chapter xi.

The volume has many of the earmarks of an analytical treatise on the relationship between international and domestic law in the American constitutional system; indeed, it has considerable value as a contribution to understanding of the intricacies of that relationship. However, it is clear that the book is an exercise in advocacy, rather than in analysis pure and simple. McClure favors the creation of a world legal order, marked by the genuine subordination of states, with their particular legal systems, to the all-encompassing and overriding authority of a global legal system.

McClure's advocacy has the important virtue of being based upon an awareness and understanding of the international legal system which is in being and in process of evolution. Enthusiasts for world law all too often betray an abysmal ignorance of international law-an ignorance which they are unwilling to remedy because they assume that international law is meaningless and worthless. They can dispose of international law in one quick glance, with one negative comment about its significance, and then move on to the suggestion that mankind must start from scratch to create an overarching legal order. To his great credit, McClure avoids this error. $\mathrm{He}$ is willing to examine the law of the past and present before having his say about the law of the future. Moreover, he is realistic enough to envisage the creation of world law as a developmental process-involving the transformation of the present system of international law into a more adequate system-rather than to postulate a juridical leap from assumed anarchy to desired order.

Indeed, the author regards that process as an operative phenomenon. He is impressed by twentieth-century trends in international law and organization-the legal prohibition of 
aggression, the assertion of the principle that individuals are internationally liable for "crimes against peace," the concept that the principles of the United Nations Charter are valid even for states outside the organization, the evolving formal authority and competence of organs of the United Nations and other multilateral institutions, etc. In short, he argues that a hopeful movement toward a world legal order is already under way.

McClure's evaluation of recent trends can be criticized as excessively optimistic. To this reviewer, he appears rather too determined to see things in a hopeful light. It is perhaps revealing that he chooses to relegate to a footnote his discussion of the incapacity of the United Nations to mitigate the Hungarian tragedy of 1956 , while he gives more prominent treatment to the more encouraging experience of the United Nations in handling the simultaneous Suez crisis (pp. 244-45). Nevertheless, it must be said that McClure provides a salutary antidote to the widespread tendency to equate pessimism with realism. We need to be reminded that grimness is not an essential criterion of the validity of facts; an alleged fact is not necessarily untrue merely because it is hopeful. A man who is looking for signs of progress toward a world legal order is entitled to take note of concepts which have been established in principle, even though little or no progress may have been made in assuring their effective application. It is a curious commentary on our present-day mentality that a world government advocate might well dismiss the evolution of a principle of order under United Nations auspices as inconsequential, while he would regard the incorporation of the same principle in a world constitutional document as a magnificent achievement; or that a "realist" would not challenge the tough-mindedness of a scholar who discovered "sovereignty" as a meaningful principle in contemporary world affairs but would look askance at
McClure for his assertion that principles making for international orderliness are evolving. To put it bluntly, a scholar can purchase immunity from having his realism called into question by the simple expedient of refusing to see anything particularly promising in recent international legal and organizational developments. McClure displays admirable intellectual integrity in refusing to join the conformity of pessimism and insisting instead that a true scholar ought to be capable of looking a fact in the eye, even though it be an encouraging and heartening fact.

Another major virtue of McClure's work lies in his frank recognition that there is much which the United States can and should do to promote the development of a more effective international legal order. Americans have a passion for the "rule of law" and a predilection for exhorting the world to adopt this formula; McClure reminds us that our national deeds have not comported with our national words. Specifically, he challenges the notion that our constitutional order requires that international legal obligations should be subordinated to domestic-law manifestations of the national will. His analysis of the treatment of the international law problem by American courts leads him to the conclusion that they have expressed a nationalistic bias in developing such concepts as the inapplicability of provisions of "non-self-executing" treaties until and unless Congress passes implementing legislation, and the judicial duty to treat a later federal statute as legally superior to an earlier treaty. These rules are not, he argues, either constitutionally necessary or logically tenable; rather, they represent a long-standing American unwillingness to tolerate the notion of a superior legal order, limiting national legal sovereignty, which Americans have made the object of such eloquent lip-service. The author notes that a number of other states have been modifying their constitutional schemes to facilitate their 
operating under a superrening system of international law, while the United States has narrowly defeated the Brickerite move to shift our system in precisely the opposite direction.

A major thesis of the book is that the United States should, by constitutional reinterpretation or by constitutional amendment if necessary, recognize that international law -whether deriving from treaties or from custom-is unconditionally superior in authority to any variety of American domestic law. There is merit in McClure's contention that concrete action of this sort would contribute more to the prospects for a world legal order than a continuing flow of pious speeches about "the rule of law."

The author's insistence on this point is illustrative of another meritorious feature of the work: its recognition that a world legal order can be achieved only with the support of and through favorable action by national states. This might seem self-evident, but it is a fact that much contemporary advocacy of world law is animated by an escapist urge to ignore national states into oblivion, to move toward a universal legal order by going around rather than through national instrumentalities. In this view, the incorrigible national state is an obstacle which must be bypassed in the march to a global order. Surely McClure is on sounder ground than this when he takes his stand on the proposition: "The appropriate procedure with respect to the world community would seem to be the development of national constitutions as the ties binding nations to the world community rather than the use of supravening law alone to bring about that end" (p. 206). The nations may not build an effective international order, but it assuredly will not be built despite them, by some massive upsurge of a global general will which enables "humanity," brushing national political institutions aside, to act as a single constituent force. If a world legal order is to be created, this will result not from the fact that states have been out-maneuvered but from the fact that their support has been enlisted for the enterprise.

As world law schemes go, then, this one has much to commend it. The present reviewer's basic quarrel is with the central theme of world law schemes in general, this one included. That theme is the efficacy and sufficiency of law as an instrument of social order; it carries with it a tendency to demean the significance of political processes while stressing the order-creating potential of legal processes.

McClure is clearly a law-stresser. He wants the world "made safe for law-sovereignty" (p. 326). He suggests that "It may be primarily through the instrumentality of the courts of law at all levels ... that the greatest objective of statesmanship, a law-abiding world, will eventually be chiefly maintained" (p. 69). He envisages a "universal society with its world-wide cooperation through a social creation, law, with the minimal political apparatus necessary to keep law modern, just, effective, and impartially enforced" (p. 323). $\mathrm{He}$ indorses President Eisenhower's statement that "In a very real sense the world no longer has a choice between force and law. If civilization is to survive, it must choose the rule of law" (p. 323).

While the author concedes the requirement of a "minimal political apparatus" to function as handmaiden of the law, it is clear that he regards law, not politics, as the key to order. His incapacity to think in political terms is strikingly illustrated when he cites a passage from United Nations Secretary-General Hammarskjöld in which the latter asserts that the "greatest need today is to blunt the edges of conflict among the nations. . . . If properly used, the United Nations can serve a diplomacy of reconciliation. . . "McClure agrees completely and draws from Hammarskjöld's statement the surprising conclu- 
sion that "workers for world legal order must concern themselves fundamentally with the matter of selecting judges who can command universal respect. . . , and they must encourage more law-making ..." (pp. 320-21). Here is the Secretary-General pleading for a more effective international political process and McClure automatically translating it as a plea for laws and judges! McClure expresses the hope that the General Assembly may become a genuine law-making body, and he makes the curious proposal that the American delegation to the Assembly should be headed by the President in person and staffed and supported by an administrative apparatus completely divorced from the State Department. "Since the purpose of the representation is participation in a supranational legal order, it would seem that it had better not be joined to the machinery of the United States government for carrying on traditional international relations. .." (p. 301). The State Department, it seems, is concerned with world politics, which must be carefully excluded from a system of world law.

In the opinion of this reviewer, we can make little progress toward world order until we cease thinking of politics as a dirty word and of law as a magic wand. Americans in particular need to be emancipated from the illusion that social peace and order are the fruits of "the rule of law." A strong case could be made for the proposition that the United
States owes its domestic tranquillity to "the rule of politics." The truth is that both legal and political processes contribute to the maintenance of order in our society. It is submitted, however, that the primary burden of managing the conflicts which might tear asunder a modern pluralistic society falls upon the politicians, specialists in the accommodation of interests, rather than upon the judges, specialists in the declaration of rights and duties. It might be recalled that our Civil War occurred soon after the judges dismantled the delicate framework of compromise which the politicians had constructed.

The problem of averting an international civil war demands not that international politics be eliminated but that the international political process be improved. Law is not the sole alternative to violence, and it may not be as promising as the alternative of politics. If the world is to be saved from destruction, we need to develop a more sophisticated understanding than we have yet achieved of the interrelationship between legal and political processes as mechanisms of order. Such an understanding will not be promoted by law-stressers who brush politics aside as unworthy of notice or acceptance.

R E F E R E N C E

1. McCluhe, Wallace. World Legal Order. Chapel Hill: University of North Carolina Press, 1960. 